\title{
A Study on the Impact of Financial Literacy on the Financial Behaviour of College Students
}

\author{
Mahima Ninan', Anu Kurian² \\ ${ }^{1}$ Student, ${ }^{2}$ Assistant Professor \\ Saintgits Institute of Management, \\ Kottayam, Kerala, India
}

\begin{abstract}
Financial literacy is increasingly vital as it has become essential that individuals acquire the skills to be able to survive in modern society and cope with the increasing diversity and complexity of financial products and services available. Financial literacy is the ability to take effective and sound decisions regarding the use and management of money. In the current era, no one can deny the importance of proper decision-making in the finance sector. If someone is not having enough financial literacy, how can he or she plan for a secure future! Especially when we talk about financial literacy among the students it is always a big matter because ultimately, they are the future of the country. The main objective of the study is to analyse the impact of financial literacy on the financial behaviour of college students. And also, the study examines the level of financial literacy among college students in India by evaluating the influence of various demographic factors like gender, type of courses, and income. The demographic, as well as financial behaviour and financial literacy, are the variables used in this study. Regression proved that there is a statistically significant influence of financial literacy on the financial behaviour of the students. And also, the demographics of student has a significant relationship with financial literacy.
\end{abstract}

Keywords: Financial Literacy, Financial Behaviour, Financial Planning, Saving Behaviour, Credit Behaviour

\section{Introduction}

"Financial literacy means knowledge and the ability to understand and apply different financial skills effectively on various financial areas including personal finance management, budgeting and investing." The people should need proper plans for the long-term investments for their future aspects of emergency needs. On the other hand, they should hold strong financial literacy about personal finance to decide on investment, especially students when they will start to earn. Additionally, they must manage their own medical as well as life insurance needs. Nowadays, the younger generation, especially college students are lacking the financial knowledge to make financial decisions. They love spending rather than saving. By keeping the future in mind, the students should develop the habit of saving and investing their money in various financial instruments. They should be aware of the various financial services and facilities provided by the banks and financial bodies which will influence them to make sound decisions and to plan a safe and better future with a financial backup by not being dependent on anyone. Over the past two decades, both developed as well as developing countries have become increasingly concerned about the level of financial literacy of their citizens, particularly among young people.

To be financially literate is important to make good financial decisions. Young adults especially college students are facing a tough financial decision in today's demanding financial environment which will affect their financial behavior. This research objective is to find out the influence of financial literacy on financial behavior and how financial behavior influences saving behavior, credit behavior, and financial planning of college students.

- To study the association of financial literacy with various students' demographics

- To analyze the effect of financial literacy on the financial savings behavior of college students.

- To analyze the effect of financial literacy on the financial credit behavior of the students.

- To analyze the effect of financial literacy on the financial planning of the students.

\section{Literature Review}

Financial Literacy

Many previous studies have assessed a range of measures of financial literacy, including objective and subjective measures, and self-reported intentions and behaviours (Paul Gerrans, 2019). Kutlu Ergun (2018), in his study regarding financial literacy among university students, stated that the lack of financial literacy has an impact on the ability of individuals to fulfill long-term goals such as home purchase, tertiary education, and pension financing. Education and money attitude found to have positive significance in financial literacy (Muhammad Albeerdy, 2015). The factors that influence the financial literacy level in both developed and nondeveloped economies in general at a macro level are age, gender, educational (Vivek Kumar,2015) People with different age groups have their different level of financial literacy. Many things are dependent on the level of financial literacy as consequences.

\section{Saving Behaviour}

The effects of the financial education courses at different levels and in different combinations high school, college, and employer are great and more significant for long-term behaviors than short-term behaviors (Jamie Wagner, 2019). Interference that foster financial information access are crucial for enhancing the financial literacy and financial literacy is crucial as this has a positive 
effect on individual saving behavior (Conrad Murendo, 2017). Financial behavior as whole has significant positive correlations with all the dimensions of financial literacy and financial literacy has proved to facilitate student's involvement in savings and investment, freeing themselves from debt, effective money management through living on a budget (U.C. Edirisinghe, 2017). The parental norms, perceived financial literacy and attitude towards money play a significant role on money management (Sheela Devi D. Sundarasen, 2017). The knowledge and understanding of finance are not enough to make a change in financial behaviour. Therefore, it takes self-control, motivation, and social skills which can help the students to behave better in terms of managing money (Azizah Fauziyah, 2016).

\section{Credit Behaviour}

Financial literacy is mostly concerned with the financial behavior including financial planning, continuing wealth accumulation and having better financial decision making (Jamal Mohammed Esmail Alekam, 2018). The more knowledge about personal finance reduced risky paying behavior (Jing Jian Xiao, 2014). Financial behaviors are affected by a large number of internal factors such as personality, individual psychology and cognition, family history, and environment (Tahira K. Hira, 2012).

\section{Financial Planning}

Financial literacy helps individuals to make well-informed financial decisions and the improvement in financial literacy will have a positive effect on accessing the personal financial planning services (Vinod Krishna M. U, 2019). One of the aspect which will be influenced by financial literacy is financial planning and it is important to individual's financial wellbeing (G Surendar, 2017).

The impact of financial literacy on financial behaviorof college students has received increasing research attention. From the above studies, it is inferred that financial literacy is highly influenced by various factors including demographic factors like gender, income, education etc. These studies stated the need to know the impact of financial literacy among the college students is inevitable. Hence, this study underwrites to the literatures by investigating the impact of financial literacy on the financial behavior of college students.

\section{Method}

The present study is focus on the association between financial literacy and financial behaviour among college students in several ways to prospectively test whether the financial literacy is associated with the financial behaviour among college students. Further, the study examines how the financial literacy influence the financial behaviours, specifically credit behaviours as well as the saving behaviour of students in this study.

\section{Context}

The Primary data collection method is used for collecting the data and using the questionnaire the data were collected from the students. The questionnaire is designed in a simple and easy manner so that everyone can understand it. The questionnaire is developed based on the study and questions were for understanding the impact of financial literacy on the financial behaviour of the college students. Most of the questions were multiple choice questions using the Likert scale. For analyzing the collected data SPSS package is used.

\section{Participants}

The survey was conducted on random basis. The questionnaire has been prepared and send to college students under the age group ranging 18-25. The sample size taken for the study was from 250 respondents. Female respondents are majority in number. Most of the students are doing their PG which include $47.8 \%$ of MBA students. There are $17.3 \%$ of students receive Rs. 15000 above in a month and $45.1 \%$ of students receive below Rs.5000 in a month.

Table 1 shows the descriptive statistics of the present study is as furnished which describes the characteristics of the population and table 2 show the descriptive statistics of financial behavior. Female students are majority in number. 
Table 2 - Descriptive Statistics of financial behaviour

\begin{tabular}{|c|c|c|c|}
\hline & $\mathrm{N}$ & Mean & Std. Deviation \\
\hline Have you taken a course in personal finance? (FL1) & 255 & 3.494 & 1.9418 \\
\hline I am able to take financial decisions (FP1) & 255 & 4.235 & .7630 \\
\hline I am aware of financial products (FL2) & 255 & 3.957 & .7169 \\
\hline $\begin{array}{l}\text { I can understand the basic principles of investing and make safe investments } \\
\text { (FL3) }\end{array}$ & 255 & 3.776 & .8139 \\
\hline I feel satisfied in controlling the finance (FP2) & 255 & 3.753 & .7873 \\
\hline Before buying something I carefully consider whether I can afford it (FP3) & 255 & 4.584 & .6458 \\
\hline I pay my bills on time (FP4) & 255 & 4.490 & .7201 \\
\hline I keep a track on my expenses on a regular basis (FP5) & 255 & 4.090 & 9069 \\
\hline I save regularly to meet my financial goals (SB1) & 255 & 3.922 & .8749 \\
\hline $\begin{array}{l}\text { Before committing to a financial decision, I consult independent sources of } \\
\text { information/advice (FP6) }\end{array}$ & 255 & 3.812 & .8534 \\
\hline I set aside money for an emergency (SB2) & 255 & 4.122 & .8722 \\
\hline I save to acquire assets (SB3) & 255 & 4.271 & .9523 \\
\hline I use to keep money for entertainment (SB4) & 255 & 3.792 & .6930 \\
\hline I save to pay off my debts (SB5) & 255 & 3.459 & .8903 \\
\hline I save to keep my life insured (SB6) & 255 & 3.820 & .7035 \\
\hline I save for making purchases(SB7) & 255 & 3.980 & .8439 \\
\hline I use credit card for availing credit (CB1) & 255 & 2.333 & 1.3291 \\
\hline I usually max out credit card limit (CB2) & 255 & 2.059 & 1.2361 \\
\hline I withdraw cash using credit cards (CB3) & 255 & 2.424 & 1.3722 \\
\hline I use payday loans (CB4) & 255 & 2.125 & 1.2580 \\
\hline Relatives (FL4) & 255 & 4.231 & 1.0298 \\
\hline Friends (FL5) & 255 & 3.824 & .6182 \\
\hline Colleagues (FL6) & 255 & 3.306 & .7790 \\
\hline Neighbors (FL7) & 255 & 2.647 & .9227 \\
\hline $\begin{array}{l}\text { Financial advisors of banks insurance companies or financial service providers } \\
\text { (FL8) }\end{array}$ & 255 & 3.482 & .8822 \\
\hline I do not talk with any of these persons about financial topics (FL9) & 255 & 2.137 & 1.2923 \\
\hline Personal financial planning involves (FP7) & 255 & 4.208 & 1.2004 \\
\hline You will improve your creditworthiness by (FP8) & 255 & 4.067 & 1.2453 \\
\hline
\end{tabular}

Table 3 - Reliability Statistics

\begin{tabular}{|c|c|c|c|c|}
\hline Variables & Cronbach's Alpha & N of Items & Reference & Description \\
\hline Financial Literacy & .847 & 9 & $\begin{array}{c}\text { Reference value }=\mathrm{a}> \\
0.70\end{array}$ & Reliable \\
\hline Financial Behaviour & .718 & 19 & & Reliable \\
\hline
\end{tabular}

Reliability test was conducted to examine whether the items of a particular constructs construe the single concept from different dimensions or otherwise. It also shows inter item consistency. Cronbach's alpha test was applied to check the reliability. The suggested value of Cronbach's alpha should be at least 0.50 If the Cronbach's alpha is greater than .70, then the reliability is acceptable; above 0.80 indicates good reliability and above 0.90 indicates the reliability is excellent. Since the values 0.87 and 0.718 is above 0.5, the reliability of the items used in questionnaire is well established and reliability measures of all variables are acceptable.

\section{Results}

Table 4 shows that Pearson's correlation coefficient is .806, which indicates significant association between the two variables, financial literacy and financial behaviour. This shows that the financial literacy has a significant relationship with financial behaviour. We can also see that Pearson's correlation is statistically significant as $p=0.000$, which satisfies the common cut-off for statistical significance of $\mathrm{p}<.05$. 
Table 5 - Financial literacy and Gender - Group Statistics

\begin{tabular}{|l|l|l|l|r|r|}
\hline & Gender & $\mathrm{N}$ & \multicolumn{1}{c|}{ Mean } & \multicolumn{1}{c|}{ Std. Deviation } & \multicolumn{1}{c|}{ Std. Error Mean } \\
\hline \multirow{2}{*}{ FINANCIAL_LITERACY } & Male & 101 & 32.2376 & 4.12104 & .41006 \\
\cline { 2 - 6 } & Female & 154 & 29.9481 & 4.48059 & .36106 \\
\hline
\end{tabular}

Table 6 - Independent Samples Test

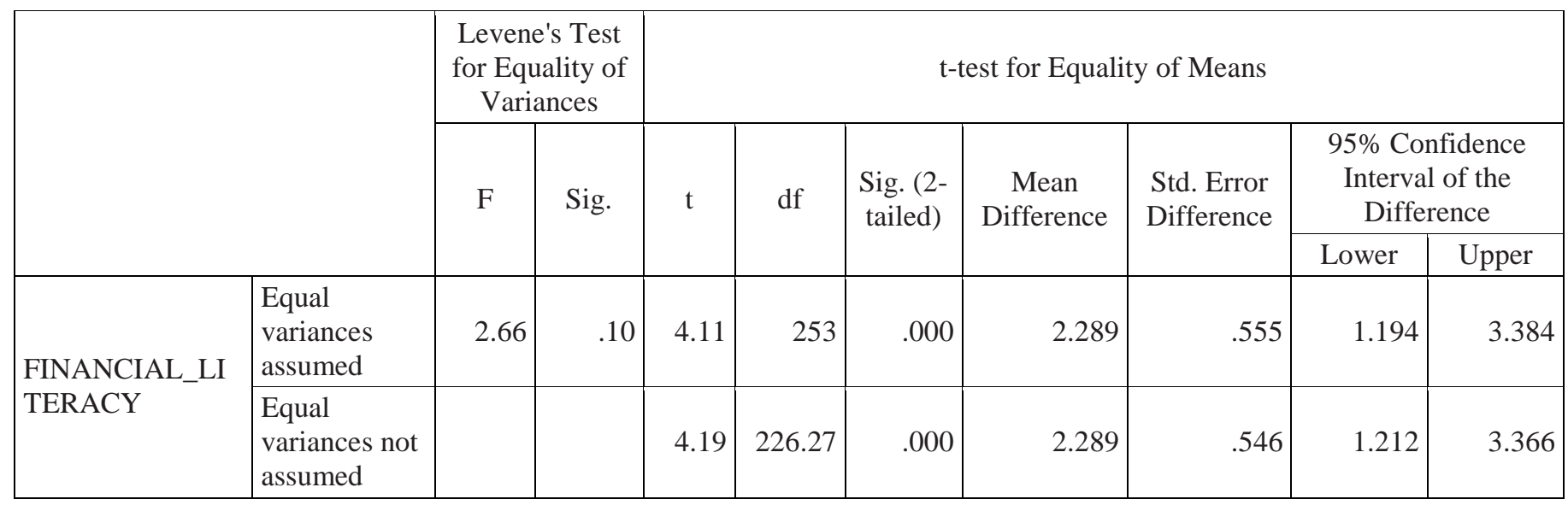

While going through the results for the t-test, the results will tell us if the means for the two groups were statistically different (significantly different) or if they were relatively the same. Sig (2-Tailed) value will tell if the two-condition means are statistically different. In this, the Sig (2-Tailed) value is 0.000. Since the Sig (2-Tailed) value is less than .05, we can interpret that there is a significant difference between the two conditions. Thus, we can conclude that there is significant difference between the financial literacy of female and male students. Male students are more financially literate than the female.

Table 7 - Financial Literacy and types of course - ANOVA

\begin{tabular}{|l|r|r|r|c|c|}
\hline & Sum of Squares & \multicolumn{1}{c|}{ df } & Mean Square & F & Sig. \\
\hline Between Groups & 233.031 & 4 & 58.258 & 2.999 & .019 \\
\hline Within Groups & 4856.600 & 250 & 19.426 & & \\
\hline Total & 5089.631 & 254 & & & \\
\hline $\begin{array}{l}\text { Dependent Variable: FINANCIAL_LITERACY } \\
\text { Predictors: TYPE_OF_COURSE }\end{array}$ & & & \\
\hline
\end{tabular}

The ANOVA table indicates that the regression model can predict the dependent variable significantly well as the significant value (0.019) is lesser than 0.05. Hence the statistical significance of the regression model that was run is established. Here it is clear that, $\mathrm{p}<0.05$, indicate that, overall, the regression model will significantly predict the outcome variable i.e. it is a good fit for the data.

Table 8 - Financial Literacy and Income - ANOVA

\begin{tabular}{|l|r|r|r|r|r|}
\hline & \multicolumn{1}{|c|}{ Sum of Squares } & \multicolumn{1}{c|}{ df } & Mean Square & F & Sig. \\
\hline Between Groups & 188.362 & 3 & 62.787 & 3.215 & .023 \\
\hline Within Groups & 4901.270 & 251 & 19.527 & & \\
\hline Total & 5089.631 & 254 & & & \\
\hline $\begin{array}{l}\text { Dependent Variable: FINANCIAL_LITERACY } \\
\text { Predictors: INCOME }\end{array}$ & & & \\
\hline
\end{tabular}

The ANOVA table indicates that the regression model can predict the dependent variable significantly well as the significant value $(0.023)$ is lesser than 0.05 . Hence the statistical significance of the regression model that was run is established. Here it is clear that, $\mathrm{p}<0.05$, indicate that, overall, the regression model will significantly predict the outcome variable i.e. it is a good fit for the data.

Multiple regression of financial literacy and financial behaviour: 
Table 9 - Model Summary

\begin{tabular}{|c|c|c|c|c|c|c|c|c|c|}
\hline \multirow[b]{2}{*}{ Model } & \multirow[b]{2}{*}{$\mathrm{R}$} & \multirow[b]{2}{*}{ R Square } & \multirow{2}{*}{$\begin{array}{c}\text { Adjusted R } \\
\text { Square }\end{array}$} & \multirow{2}{*}{$\begin{array}{l}\text { Std. Error of } \\
\text { the Estimate }\end{array}$} & \multicolumn{5}{|c|}{ Change Statistics } \\
\hline & & & & & $\begin{array}{l}\text { R Square } \\
\text { Change }\end{array}$ & F Change & df1 & df 2 & Sig. F Change \\
\hline 1 & $.555 \mathrm{a}$ & .308 & .299 & 3.7468 & .308 & 37.181 & 3 & 251 & .000 \\
\hline
\end{tabular}

Table 10 - ANOVA

\begin{tabular}{|c|c|c|c|c|c|}
\hline Model & Sum of Squares & $\mathrm{df}$ & Mean Square & $\mathrm{F}$ & Sig. \\
\hline Regression & 1565.925 & 3 & 521.975 & 37.181 & $.000 \mathrm{~b}$ \\
\hline Residual & 3523.706 & 251 & 14.039 & & \\
\hline Total & 5089.631 & 254 & & & \\
\hline \multicolumn{6}{|c|}{ a. Dependent Variable: FINANCIAL_LITERACY } \\
\hline
\end{tabular}

Table 11 - Coefficients

\begin{tabular}{|l|r|r|r|r|r|}
\hline \multirow{2}{*}{ Model } & \multicolumn{2}{|c|}{ Unstandardized Coefficients } & Standardized Coefficients & & \\
\cline { 2 - 5 } & \multicolumn{2}{|c|}{$\mathrm{B}$} & Std. Error & Beta & \multicolumn{1}{c|}{ Sig. } \\
\hline (Constant) & 8.323 & 2.215 & & 3.757 & .000 \\
\hline SAVINGS_BEHAVIOUR & .221 & .078 & .183 & 2.837 & .005 \\
\hline CREDIT_BEHAVIOUR & .381 & .055 & .403 & 6.975 & .000 \\
\hline FINANCIAL_PLANNING & .393 & .068 & .401 & 5.778 & .000 \\
\hline \multicolumn{7}{|r|}{ a. Dependent Variable: FINANCIAL_LITERACY } \\
\hline
\end{tabular}

The ANOVA table (table 10) indicates that the regression model can predict the dependent variable significantly well as the significant value $(0.000)$ is lesser than 0.05 . Hence the statistical significance of the regression model that was run is established. Here it is clear that, $\mathrm{p}<0.05$, indicate that, overall, the regression model will significantly predict the outcome variable i.e. it is a good fit for the data.

\section{Discussion}

The research examined how the level of financial literacy influences students' financial behaviour. It also analyzed the relationship between the financial literacy and the respondents' demographic data, characteristics such as: gender, income and type of course they are doing. It can be suggested that the financial difficulties might have the effect of increasing the responsibility of students on their financial planning and improving financial literacy. Courses in personal finances can be offered to students in campus and these should be made mandatory for all disciplines. These courses should provide practical experience, promoting involvement as well as transfer of knowledge and financial management skills to students. Websites providing financial information can be launched which offer free independent financial knowledge to youth and these websites must be carry out to educate the public on a wide range of financial topics. Professionals from banks can organize awareness programs for college students regarding different kinds of investment schemes and all, so that students can able to choose the right savings and investments for themselves.

\section{Limitations and Future Research}

The present study investigated the impact of financial literacy on the financial behaviour of the college students in Kerala, India. The sample size was 250 , which is very limited for a good study. In this study human behavior plays a central role, and it is always harder to understand human behavior because it is very complicated to study. Since financial behavior is related to human behavior study, and its very hard to predict. The impact of socialization agents,investment knowledge can be included in the further scope of this study.

\section{Conclusion}

Financial literacy has become a notable challenge in today's society especially among the youth or young generation. It will help the young generation to make good financial commitment. To be financially literate is very important in order to make a good financial decision. Young adult especially the college students are facing tough financial decision in today's demanding financial environment and that will affect their financial behavior. And in current era no one can reject the importance of proper decision making in the finance sector. The financial literacy among students is always a crucial matter because eventually they are the future of the country. Hence, the research found the influence of financial literacy on financial behavior of college students. 
This study used a questionnaire instrument to survey a sample of 255 college students to determine the impact of their financial literacy on financial behaviour and to assess the relationship between financial literacy and demographic attributes of these students. The hypothesis result showed that gender, type of course and Income are significantly associated with the financial literacy of an individual. As the research focused on college students, taking the age group between 18-25, young age group making them the perfect respondents as they might start earning in upcoming years, so they are going to be the foundation of the economy. This study is directed to impart the conclusions about the levels of financial literacy among the college students and found that it ranged to moderate level of knowledge. The research examined how the level of financial literacy influences students' financial behaviour. It also analyzed the relationship between the financial literacy and the respondents' demographic data, characteristics such as: gender, income and type of course they are doing.

To conclude, we can observe that gender, education or the type of course, income, and financial behaviour have a direct influence of financial literacy among students. Type of course was proven to have the significant relationship with financial literacy of the students. Financial behaviour of the students is measured on the basis of the savings behaviour, credit behaviour and their financial planning and it was also found to have a significant relationship with financial literacy of students. Based on current finding, it can be seen that family and friends had the main influence for students in terms of managing their money followed by Peers.

\section{Author Note}

We have no conflicts of interest to disclose. Correspondence concerning this article should be addressed to Anu Kurian, Saint gits Instiute of Technology, Kottayam, Kerala, India. Email: anu.k@ saintgits.org

\section{References}

[1] Paul Gerrans, Richard Heaney. (2019), The impact of undergraduate personal finance education on individual financial literacy, attitudes and intentions. Accounting and Finance, 59, 177-217

[2] Dr. Vijetha S. Shetty, Baby Jaison Thomas. (2019), A Study On Financial Literacy Amongst The College Students In Mumbai. Tactful Management Research Journal

[3] Fen Liu, Tansel Yilmazer, Cäzilia Loibl, Catherine Montalto. (2019), Professional financial advice, self-control and saving behaviour. International Journal of Consumer Studies, 43, 23-34

[4] Adriaan Kalwij, Rob Alessie, Milena Dinkova, Gea Schonewille, Anna Van Der Schors, Minou Van Der Werf. (2019), The Effects of Financial Education on Financial Literacy and Savings Behaviour: Evidence from a Controlled Field Experiment in Dutch Primary Schools. The journal of consumer affairs, Volume 53, 699-730

[5] Jamie Wagner, William B. Walstad. (2019), The effects of financial education on short-term and long-term financial behaviours. The journal of consumer affairs, Volume 53, 234-259

[6] Vinod Krishna M U, Dr. Ruchi Gupta, Dr U N Lakshman. (2019), Effect of Financial Literacy on Personal Financial Planning: A Study of Bengaluru City. International Journal of Business and Management Invention (IJBMI), Volume 8 Issue 2, Series. IV

[7] Kutlu Ergun. (2018), Financial literacy among university students: A study in eight European countries. International Journal of Consumer Studies, 42, 2-15

[8] Jamal Mohammed Esmail Alekam, Madya Salniza Bt Md, Salleh. (2018), The Effect of Family, Peer, Behavior, Saving and Spending Behavior on Financial Literacy among Young Generations. International Journal of Organizational Leadership, 2018, Volume 7

[9] C. Murendo, K. Mutsonziwa. (2017), Financial literacy and savings decisions by adult financial consumers in Zimbabwe. International Journal of Consumer Studies, 41, 95-103

[10] U. C. Edirisinghe, Y. M. S. Keerthipala, A. R. Amarasinghe. (2017), Financial literacy and financial behaviour of management undergraduates of Sri Lanka. International Journal of Management and Applied Science, Volume 3

[11] Sheela Devi D. Sundarasen, Muhammad Sabbir Rahman. (2017), Attitude Towards Money: Mediation to Money Management. Academy of Accounting and Financial Studies Journal

[12] G Surendar, V V Subramanya Sarma. (2017), Financial Literacy and Financial Planning among Teachers of Higher Education - A Comparative Study on Select Variables. Amity Journal of Finance, 2 (1), 31-46

[13] Azizah Fauziyah, Siti Aty Ruhayati. (2016), Developing Students' Financial Literacy and Financial Behaviour by Students' Emotional Quotient. Advances in Economics, Business and Management Research, Volume 15 